\title{
Quality Assessment and Comparison of Three Different Types of Fish Retail Outlets of Navi Mumbai, Maharashtra, India
}

\author{
L. Narasimha Murthy ${ }^{1 *}$, A. Jeyakumari ${ }^{1}$, Girija G. Phadke ${ }^{1}$, \\ U. Parvathy' ${ }^{2}$, S. Visnuvinayagam ${ }^{2}$ and C.N. Ravishankar ${ }^{2}$
}
${ }^{1}$ Mumbai Research Centre of ICAR-Central Institute of Fisheries Technology, CIDCO Admin Bldg., Sector - 1, Vashi, Navi Mumbai, Maharashtra - 400 703, India
${ }^{2}$ ICAR-Central Institute of Fisheries Technology, CIFT Junction, Willingdon Island, Matsyapuri, Kochi, Kerala - 682 029, India

*Corresponding author

\begin{tabular}{|l|}
\hline K e y w o r d s \\
$\begin{array}{l}\text { Supermarket fish, Dry } \\
\text { fish, Biochemical } \\
\text { quality, } \\
\text { Microbiological } \\
\text { quality, Formaldehyde }\end{array}$ \\
\hline Article Info \\
\hline $\begin{array}{l}\text { Accepted: } \\
\text { 04 July 2019 } \\
\text { Available Online: } \\
\text { 10 August } 2019\end{array}$ \\
\hline
\end{tabular}

\section{Introduction}

Fish is nourishment food in human diet supplying proteins, lipids, essential amino acids, vitamins, minerals and other nutrients. Hence, it has been attracted human consumption due to its rich source of vital nutritional components. Since, the fishes are highly perishable commodity various taken for seafood safety.
In India, fish consumers prefer three types of retail markets viz., local dry fish market, local fresh fish market and supermarket wherein no stringent food safety measures are followed and monitored. Hence, the present study was planned to analyze food safety parameters for different outlets by collecting equal numbers of fish samples from all three markets of Navi Mumbai region. Proximate composition, biochemical and microbiological parameters were evaluated. Antibiogram for the isolated Staphylococcus aureus and Escherichia coli from these fishes was studied. In dry fish market, most of the fish had higher total volatile basic nitrogen (TVB-N) and formaldehyde than permissible level. In present evaluation, formaldehyde content of fishes from different markets exhibited a higher percentage (1.03-1.93 $\mathrm{mg} \%)$ than the recommended value. Local retail fresh fish market samples had higher levels of Aerobic Plate Count (APC), E. coli and S. aureus. One sample from dried fish market exceeded the permissible limit of APC $(2,36,000$ $\mathrm{cfu} / \mathrm{g})$. Supermarket samples contained all the microbial and biochemical levels within the limit but exhibited higher formaldehyde content. Multiple drug resistant bacteria also existed in both local and supermarket samples. Monitoring authorities of India need to monitor the quality of fish in different markets at regular interval and strict action may be preservation techniques such as chilling, freezing, canning, salting drying, etc. were followed to for the fish preservation. Among the preservation techniques, sun drying is important conventional and cheaper method of fish keeping. Approximately $20 \%$ of marine fish catch by artisanal fishing operations is subjected to sun drying operations and sold in local markets (Mukharjee et al., 1990). 
External appearance and sanitary quality of fresh and sun dried fish products in domestic market does not meet the standard for human consumption as a result of improper handling practices, unhygienic processing leading to contamination causing spoilage. Stringent quality control tests are available for fish and fishery products meant for export, no such control exists for fish available in markets resulting in availability of poor quality and contaminated fish in markets which pose a serious health hazards to the consumers.

Formaldehyde is chemical having a potential antimicrobial activity but, it is highly carcinogenic in nature. Numerous reports are available about the addition of formaldehyde to the fish to retain the freshness of the fish (Bianchi et al., 2007; Noordiana et al., 2011; Joshi et al., 2015). But, small amount formaldehyde has been produced from the fish and shell fishes due to metabolism. Numerous, reports are available regarding the retail market quality of fishes (Iyer et al., 1986).

But, there no reports are available about the comparison of all three markets of Navi Mumbai region. Hence, this study was taken up for quality evaluation of fry fish, local market fresh fish and super market fish from Navi Mumbai.

\section{Materials and methods}

\section{Raw material}

Five numbers of different varieties of fish were collected from each market of dry fish market, local retail outlet and super market of Navi Mumbai region. Dried fish samples were brought to the laboratory in aseptic condition by keeping them in polythene bags whereas, fresh fish samples from local retail outlet and super market were brought to laboratory by keeping them in ice in 1: 1 ratio. All the fish samples were analyzed immediately.

\section{Proximate composition and biochemical analyses}

Proximate composition analysis containing moisture, crude protein, crude fat and ash content as well as salt content, peroxide values and formaldehyde content were evaluated as per the AOAC (2005). The moisture content of meat was estimated by hot air oven method. The crude protein content of the meat was determined by estimating total nitrogen content by Kjeldahl method. The crude fat content of meat was estimated by Soxhlet extraction method whereas ash content was calculated by keeping the samples in muffle furnace at $550 \pm 10{ }^{\circ} \mathrm{C}$ for 5 - $6 \mathrm{hrs}$. The crucibles were removed and cooled in desiccator and weighed. Ash content was calculated from the weight difference of crucible. Tri-methyl amine nitrogen (TMA-N) and total volatile base nitrogen (TVB-N) values were estimated by Conway micro diffusion method (Beaty and Gibbons, 1937). A method described by Tarladgis et al., (1960) was followed for determination of thiobarbituric acid (TBA) values.

\section{Microbiological analyses}

A method described in FAO (1992) was used for determination of Aerobic Plate Count (APC) and Staphylococcus aureus. Escherichia coli and Enterobacteriaceae counts were determined as per the method described in BAM (2002). A method given by Koutsoumanis and Nychas (1999) was utilized for determination of faecal streptococci.

Antibiogram was carried out as per the standard disk diffusion assay with 0.5 McFarland standard and break points interpretation were estimated with the help of CLSI manual (CLSI, 2012; 2014). All the analyses for biochemical quality parameters were done in triplicate and the results are expressed as mean \pm standard deviations. 


\section{Results and Discussion}

\section{Proximate composition and biochemical quality}

\section{Dried fish}

Proximate composition and biochemical quality of dried fish and prawns used in the study is presented in table 1. Moisture content varied from 15.22-20.49\%. Joseph et al., (1986) have recorded a minimum of $17 \%$ moisture along Tamilnadu coast and $23.7 \%$ along Maharashtra coast. As per the recommendation of IS 14950:2001, moisture limit for the dried Bombay duck is $15 \%$. Similarly for the dried prawns is $20 \%$. MPEDA has specified $35 \%$ as the maximum moisture level for dried ribbon fish (MPEDA, 2002). All the samples had a protein content of 65.13-78.67\%. Solanki and Sankar (1988) have recorded a protein content of $61 \%$ and a lipid content of $9.20 \mathrm{mg} \%$ in salted and dried sole. Ash content varied from 11.26-14.82\%. The higher values of ash content in dry and wet salted fish may be attributed to the salt content. The ash content in salted products can be as high as $30 \%$ in heavy salted fish. TVB-N values varied between 47.60-196.01 $\mathrm{mg} \%$. High TVBN value of commercial samples has been reported by Vijayan and Surendran (2012). Connell (1980) has suggested a limit of $200 \mathrm{mg} \%$ TVBN for salted and dried fish. Joseph et al., (1986) have reported TVBN content up to $72.7 \%$ in salted anchovy and $105.0 \%$ in salted sole. The recommended level of the TMA-N value for human consumption is $10-15 \mathrm{mg} / 100 \mathrm{~g}$. Dried prawns had TMA-N value within the acceptable limit. However, all the fish samples had beyond the limit (22.40$36.41 \mathrm{mg} \%$ ). PV usually measures initiation phase of oxidative spoilage which is non sensory method for rancidity evaluation. A peroxide value of more than 20 meq $\mathrm{O}_{2} / \mathrm{kg}$ oil for fish usually gives bad smell and rancid taste (Reza, 2006). In this study, PV values for fish were within acceptable limit (1.80- 14.53 meq $\mathrm{O}_{2} / \mathrm{Kg}$ ). All the samples had acceptable level of TBA values (0.16-0.77 mg malonaldehyde/kg). Formaldehyde finds its usage as a food and fish preservative and as a disinfectant for food containers. US Environmental Protection Agency (EPA) suggested $0.2 \mathrm{mg} / \mathrm{kg}$ as oral reference dose for formaldehyde. Food act and food regulation authorities from Malaysia in 1985 suggested maximum permissible limit of formaldehyde as $5 \mathrm{mg} / \mathrm{kg}$ in fish and fishery products. In present evaluation, formaldehyde content of fishes from different markets exhibited a higher percentage (1.03-1.93 $\mathrm{mg} \%)$ than the recommended value.

\section{Local market and super marker fish}

Proximate composition and biochemical quality of fresh fish of local and super market is depicted in table 2 and 3. Most of the fishes had moisture content in the range of 72.11$79.47 \%$. Bombay duck had higher moisture of $89.80 \%$. Protein content ranged from 13.87$24.96 \%$. Results suggested that fish from different markets had good quantity of proteins, making them suitable as a part of food for health. Seafood protein content ranges from 17 to $21 \%$ depending on the fish species (Sriket et al., 2007). All samples had $\mathrm{pH}$ range of 6.36-7.35. As per Mendes (2005), the fresh fish exhibits TVB-N value of $<20$ $\mathrm{mg} \mathrm{N} / 100 \mathrm{~g}$. Moreover, values up to $<30 \mathrm{mg}$ $\mathrm{N} / 100 \mathrm{~g}$ are considered as acceptable. However, values beyond $40 \mathrm{mg}$ N/100 g sample are considered as unsuitable for human consumption. Accordingly, none of the sample from retail market and super market crossed the rejection limit. As per the recommendation by Connell (1995), TMA-N values up to 10-15 mg N/100g are suitable for fish consumption. All the samples exhibited values within the acceptable limits. PV and TBA are established for determination of lipid oxidation in seafood. Romeu-Nadal et al., (2006) reported 
that Pacific white shrimp during ice storage exhibited PV values within the acceptability limit for fats and oils $\left(10 \mathrm{meqO}_{2 /} \mathrm{kg}\right)$. Connell (1995) revealed that TBA beyond the limit of $1-2 \mathrm{mg}$ of $\mathrm{MDA} / \mathrm{kg}$ lead to development of undesirable odour. Values indicating lipid oxidation (PV and TBA) were found to be below the rejection level. Formaldehyde content in Bombay duck had higher level (1.32 $\mathrm{mg} \%)$ than other fishes $(0.01-0.50 \mathrm{mg} \%)$ collected from local fish market. Formaldehyde content of super market fish samples ranged between 0.55 to $0.75 \mathrm{mg} \%$ whereas the local fish market samples showed formaldehyde content in the range of 0.01$1.32 \mathrm{mg} \%$.

\section{Microbiological quality of fish}

\section{Dried fish}

In India, considerable amount of fishes are dried and handled in unhygienic way; hence in addition to the recommended microbial parameters, Faecal streptococci (FS) and Enterobacteriaceae (EB) were tested to analyze quality of the dry fishes. As per the Indian standard i.e., IS 14950:2001, the upper limit of the APC of dry fish is 1,00,000 cfu $\mathrm{g}^{-1}$. In the present study, among the five samples of dried fish, one sample had exceeded the permissible limit of APC i.e., 2,36,000 cfu.g ${ }^{-1}$ (Table 4). Even though, there was no visible fungal growth in all sample; fungal count of one sample was more than 1000 cfu.g $^{-1}$. Presence of mycotoxins producing fungi in dry fishes also reported in Indian dry fishes (Sivaraman et al., 2016). Consumption of such mycotoxins may give illness to the consumers. Enormous reported are available about the poor microbiological quality of fishes from dry fish markets of India and worldwide (Sulieman et al., 2014; Lilabati et al., 1999; Prakash et al., 2011). It has been observed that higher level of enterobacteria and faecal streptococci (FS) in the collected dry fish samples; it may due the drying of the fish in the unhygienic surface area. There is no limit specified by the Indian or International standard for the level of Enterobacteriaceae and FS in dry fish. But, the elevated level of the Enterobacteriaceae and FS in the dry fish indicated the poor hygienic handling practices. Recently, the pathogenic FS were also reported in the fishes (Visnuvinayagam et al., 2017). So, proper education and training has to be given to the dry fish processers to get a safe and superior quality dry fish.

Table.1 Biochemical quality of dried fish collected from dry fish market

\begin{tabular}{|l|c|c|c|c|c|}
\hline \multicolumn{1}{|c|}{ Biochemical parameter } & BD MH & BD GUJ & $\begin{array}{c}\text { Ribbon fish } \\
\text { (Lepturacanthus } \\
\text { savala) }\end{array}$ & $\begin{array}{c}\text { Acetes } \\
\text { (Acetes sp.) }\end{array}$ \\
\hline Moisture (\%) & & & $15.22 \pm 0.02$ & $19.46 \pm 0.02$ \\
tenuipes)
\end{tabular}

Where, BD MH- Bombay duck from Maharashtra; BD GUJ- Bombay duck from Gujarat; n=3 
Table.2 Biochemical quality of fishes collected from retail fish market

\begin{tabular}{|l|c|c|c|c|c|}
\hline \multicolumn{1}{|c|}{$\begin{array}{c}\text { Biochemical } \\
\text { parameter }\end{array}$} & $\begin{array}{c}\text { Bombay } \\
\text { duck } \\
\text { (Harpadon } \\
\text { nehereus) }\end{array}$ & $\begin{array}{c}\text { Seer fish } \\
\text { (Scomberomorus } \\
\text { commerson) }\end{array}$ & $\begin{array}{c}\text { Sardine } \\
\text { (Sardinella } \\
\text { longiceps) }\end{array}$ & $\begin{array}{c}\text { Mackerel } \\
\text { (Rastrelliger } \\
\text { kanagurta) }\end{array}$ & $\begin{array}{c}\text { Tilapia } \\
\text { (Oreochromis } \\
\text { mossambicus) }\end{array}$ \\
\hline Moisture (\%) & $89.81 \pm 0.01$ & $79.48 \pm 0.01$ & $77.72 \pm 0.01$ & $72.12 \pm 0.02$ & $79.12 \pm 0.01$ \\
\hline Protein (\%) & $13.87 \pm 0.02$ & $18.65 \pm 0.02$ & $18.15 \pm 0.02$ & $21.35 \pm 0.02$ & $18.06 \pm 0.02$ \\
\hline Fat (\%) & $0.48 \pm 0.01$ & $0.29 \pm 0.01$ & $1.00 \pm 0.01$ & $3.83 \pm 0.01$ & $2.55 \pm 0.01$ \\
\hline Ash (\%) & $0.90 \pm 0.02$ & $1.25 \pm 0.01$ & $1.52 \pm 0.03$ & $1.25 \pm 0.03$ & $1.16 \pm 0.02$ \\
\hline pH & $7.35 \pm 0.01$ & $7.04 \pm 0.02$ & $6.65 \pm 0.02$ & $6.36 \pm 0.01$ & $6.84 \pm 0.01$ \\
\hline TVBN (mg\%) & $2.50 \pm 0.01$ & $2.11 \pm 0.01$ & $5.58 \pm 0.02$ & $5.6 \pm 0.01$ & $5.60 \pm 0.02$ \\
\hline TMA (mg\%) & $8.41 \pm 0.02$ & $7.00 \pm 0.03$ & $13.99 \pm 0.03$ & $2.8 \pm 0.02$ & $4.20 \pm 0.03$ \\
\hline PV(millieq.O $/ \mathbf{K g})$ & $17.72 \pm 0.01$ & $8.06 \pm 0.01$ & $6.88 \pm 0.03$ & $16.69 \pm 0.03$ & $6.57 \pm 0.02$ \\
\hline $\begin{array}{l}\text { TBA (mg } \\
\text { malonaldehyde/Kg) }\end{array}$ & $0.46 \pm 0.02$ & $0.33 \pm 0.03$ & $2.21 \pm 0.02$ & $12.66 \pm 0.02$ & $0.27 \pm 0.01$ \\
\hline $\begin{array}{l}\text { Formaldehyde } \\
\text { (mg \%) }\end{array}$ & $1.32 \pm 0.01$ & $0.01 \pm 0.01$ & $0.49 \pm 0.02$ & $0.50 \pm 0.01$ & $0.48 \pm 0.01$ \\
\hline
\end{tabular}

Table.3 Biochemical quality of fishes collected from super market

\begin{tabular}{|l|c|c|c|c|c|}
\hline \multicolumn{1}{|c|}{$\begin{array}{c}\text { Biochemical } \\
\text { parameter }\end{array}$} & $\begin{array}{c}\text { Snapper } \\
\left(\begin{array}{c}\text { Lutjanus } \\
\text { johni) }\end{array}\right.\end{array}$ & $\begin{array}{c}\text { Catla } \\
(\text { Catla } \\
\text { catla) }\end{array}$ & $\begin{array}{c}\text { Salmon } \\
\text { (Eleutheronema } \\
\text { tetradactylum) }\end{array}$ & $\begin{array}{c}\text { Tuna } \\
\text { (Euthynnus } \\
\text { alletteratus) }\end{array}$ & $\begin{array}{c}\text { Mackerel } \\
\text { (Rastrelliger } \\
\text { kanagurta) }\end{array}$ \\
\hline Moisture (\%) & $77.29 \pm 0.01$ & $78.06 \pm 0.02$ & $76.46 \pm 0.01$ & $72.01 \pm 0.02$ & $77.02 \pm 0.01$ \\
\hline Protein (\%) & $22.81 \pm 0.02$ & $22.93 \pm 0.01$ & $20.72 \pm 0.01$ & $24.96 \pm 0.01$ & $21.00 \pm 0.02$ \\
\hline Fat (\%) & $0.81 \pm 0.01$ & $0.82 \pm 0.01$ & $1.14 \pm 0.02$ & $0.19 \pm 0.01$ & $1.55 \pm 0.01$ \\
\hline Ash (\%) & $1.40 \pm 0.01$ & $1.17 \pm 0.02$ & $1.16 \pm 0.01$ & $1.33 \pm 0.02$ & $1.01 \pm 0.02$ \\
\hline pH & $7.11 \pm 0.02$ & $6.83 \pm 0.01$ & $6.71 \pm 0.01$ & $6.01 \pm 0.03$ & $6.86 \pm 0.02$ \\
\hline TVBN (mg\%) & $2.80 \pm 0.03$ & $4.20 \pm 0.01$ & $4.20 \pm 0.02$ & $16.80 \pm 0.01$ & $11.20 \pm 0.01$ \\
\hline TMA (mg\%) & $1.79 \pm 0.01$ & $2.20 \pm 0.01$ & $2.20 \pm 0.01$ & $6.79 \pm 0.02$ & $5.18 \pm 0.01$ \\
\hline PV(millieq.O2/kg) & $29.50 \pm 0.01$ & $3.47 \pm 0.02$ & $6.82 \pm 0.03$ & $48.72 \pm 0.02$ & $8.26 \pm 0.01$ \\
\hline $\begin{array}{l}\text { TBA (mg } \\
\text { malonaldehyde/kg) }\end{array}$ & $0.02 \pm 0.03$ & $0.10 \pm 0.01$ & $0.50 \pm 0.02$ & $0.92 \pm 0.01$ & $2.77 \pm 0.01$ \\
\hline $\begin{array}{l}\text { Formaldehyde (mg } \\
\text { \%) }\end{array}$ & $0.56 \pm 0.01$ & $0.55 \pm 0.01$ & $0.54 \pm 0.02$ & $0.75 \pm 0.02$ & $0.55 \pm 0.01$ \\
\hline
\end{tabular}


Table.4 Microbiological quality of dried fish collected from dry fish market

\begin{tabular}{|l|c|c|c|c|}
\hline \multicolumn{1}{|c|}{ Name of the seafood items } & APC $(\mathbf{c f u} / \mathbf{g})$ & Enterobacteriaceae & $\boldsymbol{F S}$ & Fungus \\
\hline BD MH & $4.52 \times 10^{4}$ & 0 & 400 & 0 \\
\hline BD GUJ & $2.8 \times 10^{4}$ & 0 & 300 & 800 \\
\hline Ribbon fish (Lepturacanthus savala) & $2.36 \times 10^{5}$ & 400 & 300 & 0 \\
\hline Jawla (Acetes sp.) & $1.8 \times 10^{4}$ & 200 & 300 & 800 \\
\hline Kardi (Palaemon tenuipes) & $2.16 \times 10^{4}$ & 1200 & 300 & 200 \\
\hline
\end{tabular}

Where, BD MH- Bombay duck from Maharashtra; BD GUJ- Bombay duck from Gujarat; FS - Faecal Streptococci, $\mathrm{n}=3$

Table.5 Microbiological quality of fishes collected from local retail fish market

\begin{tabular}{|l|c|c|c|c|}
\hline \multicolumn{1}{|c|}{ Name of the fish } & $\begin{array}{c}\text { APC } \\
\text { (cfu/g) }\end{array}$ & $\begin{array}{c}\text { E. } \\
\text { coli }\end{array}$ & $\begin{array}{c}\text { S. } \\
\text { aureus }\end{array}$ & FS \\
\hline Bombay duck (Harpadon nehereus) & $1.80 \times 10^{5}$ & 35 & 80 & 6 \\
\hline Seer fish (Scomberomorus commerson) & $1.88 \times 10^{5}$ & 27 & 110 & 7 \\
\hline Sardine (Sardinella longiceps) & $2.62 \times 10^{5}$ & 28 & 40 & 8 \\
\hline Mackerel (Rastrelliger kanagurta) & $13.8 \times 10^{5}$ & 20 & 60 & 5 \\
\hline Tilapia (Oreochromis mossambicus) & $1.72 \times 10^{5}$ & 27 & 70 & 9 \\
\hline
\end{tabular}

APC: Aerobic Plate Count, FS: faecal streptococci count

Table.6 Microbiological quality of fishes collected from super market

\begin{tabular}{|l|c|c|c|c|}
\hline \multicolumn{1}{|c|}{ Name of the fish } & $\begin{array}{c}\text { APC } \\
\text { (cfu/g) }\end{array}$ & E. coli & S. aureus & FS \\
\hline Snapper(Lutjanus johni) & $1.08 \times 10^{5}$ & 3.6 & 60 & 2 \\
\hline Catla (Catla catla) & $7.2 \times 10^{4}$ & 0 & 56 & 0 \\
\hline Salmon (Eleutheronema tetradactylum) & $3.04 \times 10^{5}$ & 20 & 40 & 8 \\
\hline Tuna (Euthynnus alletteratus) & $9.0 \times 10^{4}$ & 28 & 84 & 3 \\
\hline Indian Mackerel (Rastrelliger kanagurta) & $6.4 \times 10^{4}$ & 20 & 34 & 6 \\
\hline
\end{tabular}

APC: Aerobic Plate Count, FS: faecal streptococci count 
Table.7 Antibiogram for E. coli of fish samples collected from local fish and super market

\begin{tabular}{|c|c|c|c|c|c|c|c|}
\hline \multirow{2}{*}{\multicolumn{2}{|c|}{ Name of the Antibiotics }} & \multicolumn{3}{|c|}{$\begin{array}{c}\text { Local fish market } E \text {. coli } \\
\text { antibiogram }\end{array}$} & \multicolumn{3}{|c|}{$\begin{array}{l}\text { Super Market } E \text {. coli } \\
\text { antibiogram }\end{array}$} \\
\hline & & \multirow{2}{*}{$\begin{array}{c}\begin{array}{c}\text { No. of } \\
\text { Isolates }\end{array} \\
15 \\
\end{array}$} & \multirow{2}{*}{$\begin{array}{c}\text { Resistan } \\
\mathbf{t} \\
0\end{array}$} & \multirow{2}{*}{$\begin{array}{c}\text { Interme } \\
\text { diate } \\
\text { resistant }\end{array}$} & \multirow{2}{*}{$\begin{array}{c}\begin{array}{c}\text { No. of } \\
\text { Isolates }\end{array} \\
6\end{array}$} & \multirow{2}{*}{$\begin{array}{c}\text { Resistant } \\
0\end{array}$} & \multirow{2}{*}{$\begin{array}{c}\begin{array}{c}\text { Interme } \\
\text { diate } \\
\text { resistan } \\
\mathbf{t}\end{array} \\
0\end{array}$} \\
\hline Amikacin & $\mathrm{AK}$ & & & & & & \\
\hline Augmentin & AMC & 15 & 5 & 1 & 6 & 0 & 1 \\
\hline Aztreonam & AT & 15 & 0 & 0 & 6 & 0 & 0 \\
\hline Cefoxitin & CX & 15 & 0 & 1 & 6 & 0 & 0 \\
\hline Cefpodoxime & CPD & 15 & 0 & 0 & 6 & 0 & 0 \\
\hline Ceftazidime & CAZ & 15 & 0 & 0 & 6 & 0 & 0 \\
\hline Ceftriaxone & CTR & 15 & 0 & 0 & 6 & 0 & 0 \\
\hline Ciprofloxacin & CIP & 15 & 0 & 0 & 6 & 0 & 0 \\
\hline $\begin{array}{l}\text { Co- } \\
\text { trimaxazole }\end{array}$ & COT & 15 & 1 & 0 & 6 & 0 & 0 \\
\hline Colistin & CL & 15 & 0 & 5 & 6 & 0 & 2 \\
\hline Gatifloxacin & GAT & 15 & 0 & 0 & 6 & 0 & 0 \\
\hline Gentamicin & GEN & 15 & 0 & 0 & 6 & 0 & 0 \\
\hline Imipenam & IMP & 15 & 0 & 0 & 6 & 0 & 0 \\
\hline Levofloxacin & LE & 15 & 0 & 0 & 6 & 0 & 0 \\
\hline Moxifloxacin & MO & 15 & 0 & 0 & 6 & 0 & 0 \\
\hline Nalidixic acid & NA & 15 & 0 & 0 & 6 & 0 & 0 \\
\hline Nitrofurantoin & NIT & 15 & 0 & 0 & 6 & 0 & 0 \\
\hline Norfloxacin & NX & 15 & 0 & 0 & 6 & 0 & 0 \\
\hline Ofloxacin & $\mathrm{OF}$ & 15 & 0 & 0 & 6 & 0 & 0 \\
\hline Tobromycin & TOB & 15 & 0 & 0 & 6 & 0 & 0 \\
\hline
\end{tabular}


Table.8 Antibiogram for $S$. aureus of fish samples collected from local fish market and super market

\begin{tabular}{|l|c|c|c|c|c|c|c|}
\hline \multicolumn{2}{|c|}{ Name of the Antibiotics } & \multicolumn{3}{c|}{$\begin{array}{c}\text { Local fish market S. aureus } \\
\text { antibiogram }\end{array}$} & \multicolumn{3}{c|}{$\begin{array}{c}\text { Super Market S. aureus } \\
\text { Antibiogram }\end{array}$} \\
\cline { 3 - 9 } & & $\begin{array}{c}\text { No. of } \\
\text { Isolates }\end{array}$ & Resistant & $\begin{array}{c}\text { Intermed } \\
\text { iate } \\
\text { resistant }\end{array}$ & $\begin{array}{c}\text { No. of } \\
\text { Isolates }\end{array}$ & $\begin{array}{c}\text { Resistant } \\
\text { Intermed } \\
\text { iate } \\
\text { resistant }\end{array}$ \\
\hline Erythromycin & E & 18 & 0 & 0 & 13 & 1 & 0 \\
\hline Azithromycin & AZM & 18 & 2 & 0 & 13 & 8 & 0 \\
\hline Clarithromycin & CLR & 18 & 1 & 1 & 13 & 0 & 0 \\
\hline Penicillin G & P & 18 & 1 & 0 & 13 & 1 & 1 \\
\hline Ampicillin & AMP & 18 & 1 & 0 & 13 & 1 & 0 \\
\hline Amoxyclav & AMC & 18 & 1 & 0 & 13 & 0 & 0 \\
\hline Oxacillin & OX & 18 & 3 & 0 & 13 & 6 & 0 \\
\hline Methicillin & MET & 18 & 4 & 1 & 13 & 5 & 0 \\
\hline Co-TrimoxazolCoe & COT & 18 & 0 & 0 & 13 & 0 & 0 \\
\hline Gentamicin & GEN & 18 & 0 & 0 & 13 & 0 & 0 \\
\hline Amikacin & AK & 18 & 0 & 0 & 13 & 0 & 0 \\
\hline Ofloxacin & OF & 18 & 0 & 0 & 13 & 2 & 1 \\
\hline Tetracyclin & TET & 18 & 1 & 0 & 13 & 0 & 0 \\
\hline Cephalothin & CEP & 18 & 1 & 0 & 13 & 0 & 0 \\
\hline Novobiocin & NV & 18 & 0 & 0 & 13 & 0 & 0 \\
\hline Vancomycin & VA & 18 & 2 & 0 & 13 & 0 & 0 \\
\hline Teicoplanin & TE & 18 & 7 & 0 & 13 & 7 & 0 \\
\hline Linezolid & LZ & 18 & 1 & 0 & 13 & 0 & 0 \\
\hline Chloramphenicol & C & 18 & 1 & 0 & 13 & 0 & 0 \\
\hline Clindamycin & CD & 18 & 1 & 0 & 13 & 1 & 0 \\
\hline
\end{tabular}

\section{Local fish market and super market fish}

As per Indian standard recommendations, the limitation for APC in fish is less than 5, $00,000 \mathrm{cfu} / \mathrm{g}$, the same for E. coli is $20 \mathrm{cfu} / \mathrm{g}$ and for S. aureus is $100 \mathrm{cfu} / \mathrm{g}$ (FSSAI, 2012; IS: 4780 - 1978; ICMSF, 1986). In the present study, among the five samples collected from the retail fish market, one sample contained higher level of the aerobic plate count (APC) than the recommended limit; four samples contained the higher $E$. coli level and one sample contained higher $S$. aureus than the recommended limit (Table 5). In total, all the samples were microbiologically unsuitable for consuming because of higher APC, E. coli and S. aureus counts. Numerous reports are available regarding the retail fish market of the fish in India, where they reported on the poor quality of fish and fish infections with bacterial pathogens (Visnuvinayagam, 2015; Visnuvinayagam et al., 2016). Fish samples collected from the super-market had the APC, $E$. coli and $S$. aureus level within the recommended limit with exception of one sample which contained higher level of $E$. coli than the recommended limit (Table 6). It was observed that, super market fish exhibited high level of formalin. It could be a reason for the lesser level of APC in fishes of the supermarket. Addition of formalin either after 
catching the fish or after reaching in the super market may be controlled by monitoring authorities. Most of the pathogens in the retail fish market are due to repeated use of contaminated water for fish cleaning. So, fish has to be cleaned in the running water to get a safe fish.

\section{Antibiogram studies}

Antibiogram against 20 antibiotics were also analyzed for the E. coli (Table 7) and $S$. aureus (Table 8) isolated from the super market and local market. In super market sample, among the six E. coli isolates - 2 isolates were resistant to Colistin and one isolate was intermediate resistant to the Augmentin (Amoxacillin and Clavulanic acid). In Local fish market E. coli isolates, among the $15 \mathrm{E}$. coli isolates - 5 isolates were resistant to Augmentin and 5 isolates were intermediate resistant to Colistin and one isolates was intermediate resistant to Cefoxitin. In super market sample $S$. aureus isolates - 8, 7, 6, 5 and 1 number of isolates were resistant to Azithromycin, Teicoplanin, Oxacillin, methicillin and Ofloxacin respectively. Likewise, in local fish markets, 7, 4 and 3 number of isolates were found resistant to Teicoplanin, methicillin and Oxacillin respectively. Two strains were resistant to Vancomycin and azithromycin. Antibiotics such as Clarithromycin, penicillin, ampicillin, Amoxyclav, Clindamycin, Chloramphenicol and Linezolid were found resistant to each one strain. Hence, it was observed that the local fish market $E$. coli and $S$. aureus were highly resistant to isolates of the super market. Dutta et al., (2015) reported that most of the $E$. coli isolates are resistant to Erythromycin (72\%) similarly, $94 \%$ of the $E$. coli isolates were intermediate resistant to Ampicillin. Presence of these types of Multi drug resistant (MDR) bacteria is increasing in most of the fishes sold in the market. Recently, the report of Methicillin resistant
Staphylococcus aureus also reported in Cochin retail fish markets (Visnuvinayagam et al., 2015; Murugadas et al., 2017) and presence of extended-spectrum $\beta$-lactamase (ESBL) producing Escherichia coli also reported in the Indian retail fish markets (Sivaraman et al., 2017). So, increased increase incidence of highly pathogenic such as MRSA and ESBL indicate the fish market becomes a reservoir of the resistant bacteria which spread infection to handlers and consumers. A person carries such type of bacteria will not respond to any recent antibiotics in future to control the infection. So, to control the spread of pathogenic bacteria in the fish market, in addition to the training on hygienic handling practices of fish to the fish retailer; a proper awareness has to be created to the public and consumer regarding role of fish market and the spread of pathogenic bacteria via fish. Consumer has to purchase the fish from the hygienic fish retail shop only, otherwise the it is difficult to change the situation. It can be concluded that, in dry fish market, microbiological quality parameters of most of the fish samples were within the limit but samples had higher TVB$\mathrm{N}$ value and formaldehyde content than the permissible level. Ironically, the local retail fish market, most of the samples' biochemical levels were within the limit; but samples exhibited higher level of APC, E. coli and $S$. aureus. In addition, one sample showed higher formaldehyde content. Even though, super market sample contained all the microbial and biochemical levels within the limit, all the samples had higher formaldehyde content. The lower microbial count in the supermarket fish sample may due to formaldehyde treatment. Multiple drug resistant bacteria also existed in both local and supermarket samples. The monitoring authority of India need to evaluate fish quality for different fish markets at regular interval and strict action has to be taken to produce safe seafood. 


\section{References}

AOAC, 2005. Official Methods of Analysis of AOAC International, Association of Analytical Chemists, $17^{\text {th }}$ edn., Gaithersburg, MD, USA.

BAM, 2002. Enumeration of Escherichia coli and the coliform bacteria In: Bacteriological Analytical Manual, United States Food and Drug Administration, USA.

Beaty, S.A., and Gibbons, N.E. 1937. The measurement of spoilage in fish. J. Biol. Bd. Canada, 3: 77-91.

Bianchi, F., Careri, M., Musci, M. and Mangia, A. 2007. Fish and food safety: Determination of formaldehyde in 12 fish species by SPME extraction and GC-MS analysis. Food Chem., 100(3): 1049-1053.

CLSI, 2012. Methods for dilution antimicrobial susceptibility tests for bacteria that grow aerobically, $9^{\text {th }}$ edn, In: Wayne P A (Eds.) Clinical and Laboratory Standards Institute approved standard M07-A9.

CLSI, 2014. Performance standards for antimicrobial susceptibility testing, twenty-fourth informational supplement. In: Wayne P A (Eds.) Clinical and Laboratory Standards Institute CLSI document M100-S24.

Connell, J.J. 1980. Control of fish quality. Fishing News (Books) Ltd., Farahans

Connell, J.J. 1995. Quality deterioration and extrinsic quality defects in raw material. In: Control of fish quality. $4^{\text {th }}$ edn, Fishing News Books Ltd. Survey, England, $241 \mathrm{p}$.

Dutta, C., Panigrahi, A.K. and Sengupta, C. 2015. Prevalence of pathogenic bacteria in finfish and shellfish obtained from domestic markets of West Bengal, India. Front Environ. Microbiol., 1(2): 14-18.
FAO, 1992. Manual of food quality control, 4.Rev. 1. Microbial analysis. FAO Food and Nutrition paper Food and Agriculture Organization of the United Nations, Rome.

FSSAI, 2012. Lab parameters for imported food \& methods for standardization. http://fssai.gov.in/Portals/0/Pdf/Final_L ab_Parameters(21-08-2012).pdf

Gopalakrishna Iyer, T.S., Damle, S.P., Garg, D.K., Nambiar, V.N. and Vasu, N.M. 1986. Quality of fish in retail markets of Bombay. Fish. Technol. 23(1): 78-83.

Huss, H.H. 1994. Traditional Microbiological Quality Control, In: Assurance of seafood quality, FAO Fisheries Technical Paper -334 . http://www.fao.org/docrep/003/t1768e/t 1768e04.htm

ICMSF 1986. International commission on microbiological specifications for foods Micro-organisms in foods 2 - Sampling for microbiological analysis: principles and specific applications, 2nd edn., Blackwell Scientific Publications, Oxford, England. http://www.icmsf.org/pdf/icmsf2.pdf

IS: 4780 - 1978 (Reaffirmed 2000) 2000. Indian standard specification for Pomfret, fresh (First Revision) Fish and Fishery Products Sectional Committee, AFDC 27, Indian Standard Institution, Manak Bhavan, 9 - Bahadur shah zafarmarg, New Delhi 110002.

ISO, International Organization for Standardization (ISO), Draft ISO/DIS (1990) 9308-9311.

Joseph, K.G., Muraleedharan, V. and Nair, T.S.U. 1983. Quality of cured fishery products from Malabar and Kerala coast. Fish. Technol. 20(2): 118-122.

Joseph, K.G., Muraleedharan, V., Kalaimani, N. and Nair, T.S.U. 1986. Quality of cured fish from Tamil Nadu coast. Fish. Technol. 23(1): 63-65. 
Joshi, R., Bhatta, R., Paudel, P.N. and Kafle, B.K. 2015. Formaldehyde content of selected fish from the wet markets of Kathmandu valley. Int. Food Res. J., 22(4): 1434-1437.

Koutsoumanis, G.K. and Nychas, J.E. 1999. Chemical and sensory changes associated with microbial flora of Mediterranean bogue (Boops boops) stored aerobically at $0,3,7$, and $10^{\circ} \mathrm{C}$. Appl. Environ. Microbiol., 65: 698-706.

Lilabati, H., Vishwanath, W. and Singh, M. 1999. Changes in bacterial and fungal quality during storage, Esomus danricus of Manipur. Fish. Technol., 36: 36-39.

Mendes, R., Goncalves, A., Pestana, J. and Pestana, C. 2005. Indole production and deepwater pink shrimp (Parapenaeus longirostris) decomposition. J. Eur. Food Res. Tech., 214: 125-130.

MPEDA 2002. Specification for dried fish. Reproduced below is the final order on export of dried fish, dt. 30-12-2002 published in the gazette of India Part-II Section 3, Subsection (ii) dt.30-122002. In: MPEDA News Letter, Marine Product Export Development Authority, Cochin, p. 10-17.

Mukharjee, S., Bondyapadhya, S. and Bose, A.N. 1990. An improved solar dryer for fish drying in the coastal belt. J. Food Sci. Tech., 27: 175-177.

Murugadas, V., Joseph, T.C. and Lalitha, K.V. 2017. Tracing contamination of Methicillin-resistant Staphylococcus aureus (MRSA) into seafood marketing chain by staphylococcal protein A typing. Food Control, 78: 43-47.

Noordiana, N., Fatimah, A.B. and Farhana, Y.C.B. 2011. Formaldehyde content and quality characteristics of selected fish and seafood from wet markets. Int. Food Res. J., 18(1): 125-136.

Prakash, S., Jeyasanta, I., Reiba, C. and Patterson, J. 2011.Microbial quality of salted and sun dried sea foods of
Tuticorin dry fish market, Southeast coast of India. Int. J. Microbiol. Res., 2(2): 188-195.

Reza, M.S. 2006. Improvement of food quality of traditional marine dried fishery products using solar tunnel drier. M.Sc. thesis submitted to the Dept. of Fisheries Technology, Faculty of Fisheries, Bangladesh Agricultural University, Mymensing, Bangladesh p. 1-136.

Sivaraman, G.K., Prasad, M.M., Jha, A.K., Visnuvinayagam, S., Renuka, V., Remya, S., Kriplani, Y. and Vanik, D. 2017. Prevalence of extended-spectrum $\beta$-lactamase producing Escherichia coli in seafood from the retail fishery outlets of Veraval, Gujarat, India. J. Environ. Biol., 38(4): 523.

Sivaraman, G.K., Visnuvinayagam, S., Jha, A.K., Remya, S., Renuka, V., Ajeesh, K. and Vanik, D. 2016. Molecular divergence and identification of Aspergillus species in dry fishes of Gujarat, India. Proc. Nat. Acad. Sci., India Sec. B: Biol. Sci., 1-11.

Solanki, K.K. and Sankar, T.V. 1988. Quality of traditionally cured (dried) fish of Saurashtra coast. In: Joseph, M.M. (Eds.) The First Indian Fisheries Forum Proceedings p. 391-393.

Sriket, S., Benjakul, P., Visessanguan, W., Kijroongrojana, K. 2007. Comparative studies on chemical composition and thermal properties of black tiger shrimp (Penaeus monodon) and white shrimp (Penaeus vannamei) meats. Food Chem., 103: 1199-1207.

Sulieman, A.M.E., Hassan, Z.M. and Elkhalifa, E.A. 2014. Microbial safety of dried fish meat (Kejeik) produced in Sudan. Food Nutr. Sci., 5: 606-613.

Tarladgis, G.B., Watts, M.B. and Younathan, T.M. 1960. A distillation method for the quantitative determination of 
malonaldehyde in rancid foods. J. Am. Oil Chem. Soc., 37: 44-50.

Vijayan, P.K. and Surendran, P.K. 2012. Quality aspects of dried fish marketed in the North Eastern states of India. Fish. Technol., 49: 167-171.

Visnuvinayagam, P., Viji, P., Murthy, L.N., Jeyakumari, A. and Sivaraman, G.K., 2016. Occurrence of faecal indicators in freshwater fishes of Navi Mumbai in retail outlets. Fish. Technol. 53: 334338.

Visnuvinayagam, S., Murthy, L.N., Viji, P. and Sivaraman, G.K. 2017. Study on retail fish markets: Possible occurrence and transmission of emerging pathogen from faecal indicators. J. Environ. Biol., 38(3): 465.

\section{How to cite this article:}

Narasimha Murthy, L., A. Jeyakumari, Girija G. Phadke, U. Parvathy, S. Visnuvinayagam and Ravishankar, C.N. 2019. Quality Assessment and Comparison of Three Different Types of Fish Retail Outlets of Navi Mumbai, Maharashtra. Int.J.Curr.Microbiol.App.Sci. 8(08): 248-259. doi: https://doi.org/10.20546/ijcmas.2019.808.030 